\title{
China's Peaceful Rise: A Necessary Path with Challenges
}

\author{
Xuanyi Zhu ${ }^{1, *}$ \\ ${ }^{1}$ School of Foreign Languages, Wuhan University of Technology, Wuhan, Hubei 430070, China \\ "Corresponding author.Email: xuanyi.zhu@whut.edu.cn
}

\begin{abstract}
In this paper, necessities as well as challenges of China's peaceful rise will be demonstrated in four sections: leading national strategies in different historical periods; current domestic and international circumstances; barriers facing in implementing a soft rise; suggested ways to ameliorate main issues in the future. Considering today's intricate international environment and China's extreme dependence on global stability, it is a peaceful strategy that has the capability to guarantee China's core interests and future development. The major obstacle, nonetheless, is posed for China to boost its international image via combining soft power with hard power together to realize China's peaceful rejuvenation without presenting big threats to the international community.

Keywords: China's grand strategy, China's peaceful rise, international image, soft power, China threat theory
\end{abstract}

\section{INTRODUCTION}

The paramount significance of grand strategy has been widely acknowledged since last century and even be regarded as the crucial "ways, means and ends" to a country's developments [1]. Domestic studies of China's grand strategy mainly started from the 21 st century when lots of Western representative literature were introduced to China and then be facilitated by Chinese scholars [2]. China's strategic goal, reviving the Chinese nation, was set by Mao Zedong and Deng Xiaoping. It has then been affirmed and enhanced by China's present leaders as well as Chinese people [3]. In recent years, with the rapidly changing global situation, Beijing has labelled a strategy of "peaceful rise" to dampen worries about its growing capabilities [4].Given today's intricate international order as well as China's increasingly significant influence on the international stage, a proper grand strategy for China is urgently needed [5]. While the international community is eager to understand China's strategic thoughts and objectives, no official documents have been disclosed by Chinese government to define its grand strategy up to now. Consequently, it is time for China to attach more importance to design its grand strategy which can reflect its core interests, safeguard against external threats, and guarantee its future development.

This paper advocates a peaceful grand strategy for China's rise after articulating its necessities as well as obstacles. Initially, this paper reviews the development of China's major grand strategies in different historical periods (from Mao to $\mathrm{Xi}$ ). It then analyses the situation China is in at present in aspects of domestic and international environments, emphasizing the necessities of a peaceful grand strategy. After that, this article discusses the major challenges for China to tackle with in the way of implementing its peaceful rise. Finally, some suggestions for China to ameliorate its international image and mitigate those main issues are proposed.

\section{RETROSPECT}

What should be prioritized before designing a national grand strategy is to set the country's priorities and interests right. Despite that no official documents have been disclosed by Chinese government to define its grand strategies until now, China's policies have been highly consistent with the country's domestic interests and priorities from the past to the present [6]. In this section, China's major strategies from Mao to now will be reviewed.

\subsection{Nation in turbulence: Mao's era}

In the era of Mao Zedong, facing serious external and internal threats, China's grand strategies were always occupied by political and military security interests. Regarding nation and party's interests as priorities, Mao put great emphases on the "principal contradiction" (Mao's argot, which means the major obstacle for China's development, whose connotation will change in different situations) all the time. During the Anti-Japanese War period, Mao formed the National United Front with various classes and parties to safeguard China's security despite different class interests and party affiliations. After Japan's defeat, due to the outbreak of Civil War between Chinese Communist Party (CCP) and Kuomintang (KMT), Mao asserted that the "principal contradiction" had transformed into the KMT regime which jeopardized the realization of a peaceful and united China, appealing for another united front, including broad classes and parties against the KMT regime, to struggle for the founding of the People's Republic of China and a stable CCP leadership. 
After the Chinese Communist Party came into power, the new strategies emphasized domestic development such as the Five-Year Plan and Great Leap Forward were implemented to foster China's economic advancement. Meanwhile, the strategies underlined national security and regime stability were also carried out considering the changing international order: the alliance with Soviet-led socialist bloc in the $1950 \mathrm{~s}$, a coalition of the "revolutionary forces of the third world" in the mid-1960s, and the alliance with the United States owing to a more hostile USSR after 1969 [7]. Therefore, it is not difficult to find that although the "principal contradiction" was given different connotations under different historical circumstances, it always had a consistent core: national and party's interests.

\subsection{Nation facing changes: Deng's choice}

Then came the leadership of Deng Xiaoping. Owing to the reduced likelihood of large-scale military conflicts with Soviet Union or the United States, as well as China's success in its nuclear capability to defend the territory and sovereign integrity, grand strategies at that time tended to attach more importance on economic constructions, especially the reform and opening up policy initiated by Deng. Then with the falling curtain of the bipolar world and the coming age of unipolar power, uncertainties of discerning China's friends and enemies increased, leading to a preference for more mild and inclusive strategies. Decisions such as the accession to WTO showed China's determination of cultivating cooperative relations with various countries in the international arena to guarantee its core interests.

Meanwhile, in spite of increasingly significant economic interests, the nation's security and sovereignty interests stayed indispensable. Without overt external military threats, China was still facing series of subtle risks such as the ideological or political corrosions caused by growing exchanges in many aspects with the Western world, the Taiwan issue, maritime sovereignty disputes in the East and South China Seas. Conspicuously, China's grand strategy was still dominated by the country's domestic priorities, including economic developments, territory sovereignty and regime stability.

\subsection{Nation in $21^{\text {st }}$ century: peaceful cooperation}

After entering the new century, China's grand strategy was increasingly inclined to a peaceful path. Under Hu Jintao's leadership, Beijing had formulated a new development and social policy geared toward continuing to promote fast economic growth while emphasizing good governance, improving the social safety net, protecting the environment, encouraging independent innovation, lessening social tensions, perfecting the financial system, and stimulating domestic consumption [6]. As $\mathrm{Hu}$ announced in 2009, China's diplomacy must "safeguard the interests of sovereignty, security and development", clearly depicting the contour of China's core interests.

So does the strategy under Xi Jinping's leadership now. "China Dream", as proposed by $\mathrm{Xi}$, is set as the national goal to realize China's great rejuvenation, regarding its own development as the principle task. Meanwhile, China's resolution to foster international cooperation and rise peacefully is articulating steadfastly. As $\mathrm{Xi}$ advanced in 2017, China must follow the road of "peaceful development" firmly and "build a community with a shared future for mankind". At the same time, the nation's military construction has never been neglected in order to safeguard China's sovereignty and security in today's unpredictable international society.

Reviewing the development history of China's grand strategy, it is obvious that the economic and social development, national sovereignty and territory integrity, as well as the stability of the CCP leadership and socialist system, have been China's priorities all the time. Hence, a peaceful grand strategy, with its ability to guarantee these priorities, is highly consistent with China's core interests and leaders' thoughts all the while.

\section{WHERE ARE WE TODAY}

In this section, necessities for China to adopt a peaceful grand strategy will be demonstrated considering both domestic and international factors. Concentrating on domestic demands to promoting its economy, modernizing its society and enhancing people's living standards, China has always put its emphases on domestic developments instead of being too aggressive in the world stage. What's more, at today's transitional point of the international order, it is China's responsibilities as well as interests to contribute to a peaceful international environment for the sake of its own development.

Two things are valuable when judging a country's potential direction of its grand strategy: leaders' objectives and social conditions. In today's China, these two aspects all require a peaceful rise strategy for its capability to best guarantee China's core interests.

Paying some attentions to the thoughts and objectives enunciated by Chinese leaders, it is explicit that they are leading China to a peaceful development path by seeking domestic enhancement and international cooperation. Back to Deng's leadership, a three-stage development plan has been set in 1987, emphasizing the economic growth in the first and second stages by the end of the 20th century, and becoming a mid-level developed country in the third stage by 2050 . Since 2003 , concepts such as a "scientific outlook on development" and "building a harmonious society" have been expounded. Today under Xi's leadership, a two-stage development plan is proposed: to build on the foundations of China's modern economy from 2020 to 2035; then to become a state with substantial global influence from 2035 to 2050. Xi has further declared in his 19th CCP Congress Report that China "has stood up, grown rich and become strong", and the major task for the next generation is to "embrace the brilliant prospects of rejuvenation since "it 
will be an era that sees China moving closer to centre stage and making great contributions to mankind". Conspicuously, Chinese leaders' national goals have always been in line with China's domestic interests especially economic gains to ensure the country's sovereignty, security and development.

With respect to the leaders' attitude toward the international society, Chinese government has always committed itself to facilitate global collaboration. The Central Committee of the CCP has clarified that China's foreign policy "must maintain economic construction as its centrepiece, be closely integrated into domestic work, and be advanced by coordinating domestic and international situations" in 2006. Furthermore, this trend has become progressively evident in recent years. As advocated by Xi, the concept such as "build a community with a shared future for mankind" has penetrated into China's policies recently through the Belt and Road Initiative and the like. Distinct from conventional international relation theory which argues that an open world economy requires a single great power in terms of hegemonic stability theory, China has practiced multilateralism with its neighboring countries since 1990s, seeking new types of partnerships and contributing to common development. For example, the Chinese government released its white paper on China's Policies on Asia-Pacific Security Cooperation in 2017, proclaiming that "the development of a regional security framework should be advanced in parallel with the development of regional economic framework".

What is equally worth noticing is that facing new changes in today's intricate international circumstance, it is a peaceful grand strategy that can boost China's rise successfully. Initially, owing to increasingly tight connections between various countries around the world, it will be imprudent for China to define any country as an enemy. Hence, instead of being country-oriented, being issue-oriented is a more sensible choice.

For instance, while the United States might form military or political threats to China, it is still one of China's most significant economic partner; while Iran is a key supplier of oil to China, its nuclear issue still tests China's official stance; while Japan and some Asian countries might involve in geopolitical conflicts with China, they are still indispensable to China in both economic cooperation and territory security; while diverse countries all over the world might generate conflicts in numerous aspects, they still need to face global issues, global warming, terrorism, epidemic and so on together.

Moreover, given China's current social situations where series of livelihood issues have not been settled thoroughly, and national goals proposed such as building an all-around well-off society, a stable and peaceful environment with the ability to guarantee sustainable economic growth is of paramount significance. Consequently, it is in China's own interests to contribute to a peaceful international community. After discussing China's domestic situations, including leaders' thoughts and social needs, as well as uncertainties in the ever-changing international society, not only is a peaceful grand strategy in accordance with Chinese wisdom, but also it can maximize and optimize China's core interests in today's elusive international order.

\section{RISING CHALLENGES}

Following this peaceful path to maintain China's sustainable development, nevertheless, poses an arduous task for its leadership: ameliorating China's international image. In this section, the main barriers for addressing this challenge will be demonstrated.

As Ramo, the proposer of "Beijing Consensus", declared in 2007, "China's greatest strategic threat today is its national image". Nowadays, policies such as the Belt and Road Initiative have caused more doubts and suspicions around the world about China's so-called real motivation. Specifically, with the prevalence of "China threat theory", a grand strategy with the capability to facilitate China's rise by reducing the likelihood its growing power will pose threats to others and provoke them to oppose China is urgently needed.

For the sake of an amicable and desirable international image, several major obstacles are supposed to be tackled initially:

(1) Chinese leaders pay much more attention to the GDP growth rather than "cultivate real affinities with foreign publics". While seeking for a large amount of exports and foreign direct investment, for example, China's diplomacy might be regarded as too pragmatic or economic-oriented, instead of creating a compatible image.

(2) Facing a "hegemony of discourse" where most of the world's news is presented within the framework of Western ideology, China neglects the effective usage of modern media. While mainstream social platforms around the world are dominated by Western media such as twitter, Facebook, Instagram and the like, Chinese ideology is to some extent isolated from the international community, deteriorating by the "wall" set in mainland China, which impedes other countries to understand Chinese thoughts correctly and creates a conservative image.

(3) Chinese culture itself is distinct from the dominating Western way, which is too culturally specific to be comprehended appropriately, setting barriers for the world to understand China's political discourse correctly. For instance, while Chinese people are accustomed to collectivism, Western people are in the habit of individualism. This discrepancy might bring misinterpretations to Western people by connecting Chinese people's frequent use of "us", "one family", and such concepts with communist ideology. Such details might create misunderstandings, let along many more profound and unfathomable concepts in Chinese culture.

(4) Usually applying the term external propaganda, China has long neglected the concept of public diplomacy. While emphasizing the advertisement of China's achievements to enhance its positive image overseas, for example, China might neglect that the role of general public is of equal importance, leading to divergences between the public and political elites, which might generate inflammatory comments. 
from the era of Mao to the present, and changing situations facing China currently. Considering China's core interests, including sovereignty, security and development, as well as regime stability, it is a peaceful strategy that is in line with China's development ideas and can best safeguard its interests in this intricate international community. After that, mainly concerning the amelioration of China's international image and the cultivation of soft power, major challenges facing China in implementing its soft rise are proposed and several opinions are given. The issues raised and discussed in this paper, nonetheless, are still lack of more comprehensive perspectives and exhaustive analysis, waiting for further researches.

To conclude, after discussing the reasons for pursuing a peaceful rise and the barriers for achieving it, China's peaceful rejuvenation is possible as well as essential for its national interests and future development. A formidable challenge posed for China now is to enhance its international image by boosting the nation's soft power, requiring a more sophisticated grand strategy.

\section{REFERENCES}

[1] P. Dombrowski, S. Reich, (2017) Does Donald Trump have a Grand Strategy? International Affairs, 93(5): 1016.

[2] H. Ge, (2018) Grand Strategy: Evolution, Logic and Application in China. World Outlook, 5: 13-14.

[3] Z. Ye, (2010) Inside China's Grand Strategy: The Perspective from the People's Republic. The University Press of Kentucky, Kentucky.

[4] A. Goldstein, (2016) The Evolution of China's Security Challenges and Grand Strategy. International Security Studies, 2(1): 56.

[5] JJ. Mearsheimer, (2019) Bound to Fail: The Rise and Fall of the Liberal International Order. International Security, 43(4): 7-50.

[6] J. Wang, (2011) China's Search for a Grand Strategy: A Rising Power Finds Its Way. Foreign Affair, 90(2): 68-79.

[7] A. Goldstein, (2005) Rising to the Challenge: China's Grand Strategy and International Security. Stanford University Press, Stanford.

\section{CONCLUSION}

In this paper, necessities of China's peaceful rise have been demonstrated from two aspects: China's leading strategies 